Administrative and managerial issues of tax reforms

\author{
ААминистративно-управленческие проблемы \\ налоговых реформ
}

DOI: $\underline{10.15826 / j \operatorname{tr} .2018 .4 .1 .042}$

\title{
Robot vs. tax inspector or how the fourth industrial revolution will change the tax system: a review of problems and solutions
}

\author{
Valentine P. Vishnevsky \\ Institute of Industrial Economics of NAS of Ukraine, Kiev, Ukraine \\ ORCID: 0000-0002-8539-0444 \\ Viktoriia D. Chekina \\ Institute of Industrial Economics of NAS of Ukraine, Kiev, Ukraine \\ ORCID: 0000-0003-2118-901X
}

\begin{abstract}
The Fourth Industrial Revolution and the accelerated development of cyber-physical technologies lead to essential changes in national tax systems and international taxation. The main areas in which taxation meets cyber-physical technologies are digitalization, robotization, M2M and blockchain technologies. Each of these areas has its own opportunities and problems. Three main approaches towards possible solutions for these new problems are identified. The first is to try to apply taxation to new cyber-physical technologies and products of their application. This approach includes the OECD's Action 1 Plan on Base Erosion and Profit Shifting. It also includes the spread of traditional taxes on new objects - personal data, cryptocurrencies, imputed income of robots. The second is to replace digital transactions and shortfalls in revenues by traditional objects of taxation in the form of tangible assets and people and / or increase tax pressure (including by improving tax administration with use of Big Data) and the degree of progressiveness of taxes already levied on such objects. The third approach is to set a course on building a new tax space with smart taxes based on real-time principles, smart contracts and Big Data. This implies a transition to automatic taxation using blockchain technologies, which focus on the functions of applying distributed ledgers of business transactions in realtime. At present, the general trends are such that the first and second are prevalent, which is manifested in an increase in the relative importance of property, sales and employment taxes. Concerning the third approach, any movement in this direction is still facing a number of technical and other problems and is thus being discussed mainly at the conceptual level
\end{abstract}

\section{KEYWORDS}

Cyber-physical technologies, digitalization, blockchain, taxes on digital goods, taxes in Big Data, taxes on robots, taxes on cryptocurrencies

JEL H20, H30

\section{HIGHLIGHTS}

1. Production technologies and taxes are dialectically linked. Therefore, the accelerated development of cyber-physical systems leads to substantial transformations of national taxes and international taxation

2. It is established that there are three main areas where taxes meet new cyber-physical technologies and where new fiscal opportunities and problems arise - digitalization, robotics, M2M and blockchain technologies

3. Three main approaches to solving emerging problems of taxation are stressed: the first entails extended tax coverage of new cyber-physical technologies and products 
of their use; the second involves the replacement of digital transactions and shortfalls in revenues by objects of taxation in the form of tangible assets and people; while the third envisages the construction of a new tax space with smart taxes based on realtime principles, smart contracts and Big Data

\title{
Робот против налогового инспектора, или как изменит налоговую систему четвертая промышленная революция: обзор проблем и решений
}

\author{
В. П. Вишневский \\ Институт экономики промышленности НАН Украины, \\ г. Киев, Украина \\ ORCID: 0000-0002-8539-0444 \\ В. Д. Чекина \\ Институт экономики промышленности НАН Украины, \\ г. Киев, Украина \\ ORCID: 0000-0003-2118-901X
}

\begin{abstract}
АННОТАЦИЯ
Четвертая промышленная революция и ускоренное развитие киберфизических технологий ведут к существенным изменениям национальных налоговых систем и международного налогообложения. Основными сферами, где налоги пересекаются с киберфизическими технологиями, являются цифровизация, роботизация и М2М, технологии блокчейн. В каждой из этих сфер есть свои возможности и проблемы. Существует три основных пути возможного решения этих новых проблем. Первый путь - попытаться охватить налогами новые киберфизические технологии и продукты их использования. Этот путь включает План действий 1 ОЭСР по противодействию размыванию налоговой базы и выводу прибыли из-под налогообложения. Он также включает распространение традиционных налогов на новые объекты - персональные данные, криптовалюты, вмененные доходы роботов (электронных лиц). Второй путь заключается в замене цифровых транзакций и выпадающих доходов традиционными налоговыми объектами в виде материальных активов и людей и / или увеличении налогового давления (в том числе путем совершенствования налогового администрирования с использованием больших данных) и степени прогрессивности налогов, уже взимаемых с таких объектов. Третий путь - взять курс на построение нового налогового мира с умными налогами, основанными на принципах реального времени, умных контрактах и больших данных. Речь идет о переходе на автоматическое налогообложение с использованием блокчейн-технологий, которые ориентированы на функции применения распределенных регистров хозяйственных операций в режиме реального времени. В настоящее время общие тенденции таковы, что преобладают первый и второй пути, что проявляется в росте относительного значения налогов на имущество, продажи и занятость. Что касается третьего пути, то движение в этом направлении все еще сталкивается с рядом технических и других проблем и обсуждается в основном на концептуальном уровне
\end{abstract}

\section{КЛЮЧЕВЫЕ СЛОВА}

Киберфизические технологии, цифровизация, блокчейн, налоги на цифровые товары, налоги в сфере больших данных, налоги на роботов, налоги на криптовалюты

\section{ОСНОВНЫЕ ПОЛОЖЕНИЯ}

1. Производственные технологии и налоги диалектически связаны. Поэтому ускоренное развитие киберфизических систем ведет к существенным трансформациям национальных налогов и международного налогообложения 
2. Установлено, что существуют три основных сферы, где налоги встречаются с новыми киберфизическими технологиями и где возникают новые налоговые возможности и проблемы - дигитализация, роботизация и М2M, технологии блокчейн

3. Выделены три основных пути решения новых проблем налогообложения: первый - охват налогами новых киберфизических технологий и продуктов их использования; второй - замена цифровых транзакций и выпадающих доходов налоговыми объектами в виде осязаемых активов и людей; третий - построение нового налогового мира с умными налогами, основанными на принципах реального времени, умных контрактах и больших данных

\section{Introduction}

A growing body of research in economic digitalization, robotization and cyber-physical systems development raises questions as to how the new industrial revolution will affect the rate of tax revenues for the treasury and the whole tax system yet more often. This issue has already been featured in many publications, not just in work by individual researchers (M. Bacache-Beauvallet and F. Bloch [1], S. Gupta, M. Keen, A. Shah, and G. Verdier [2], J. Crémer [3], X. Oberson [4], R. Shiller [5], etc.), but also in the official publications of influential international organizations and companies. For instance, the papers of Pricewaterhouse Coopers (PWC) analysed tax incentives for Industry 4.0 [6-8]. The publications of McKinsey Global Institute and Deloitte, the multinational professional audit services network, reflect the interconnection between taxes and new manufacturing technologies [9-11]. Ernst \& Young has produced publications devoted to issues of taxation in the digital economy, including the possible use of blockchain technology [12; 13]. In the publications of OECD committees and working parties, much attention is being paid to tax evasion in the digital economy and tax administration, including using the Big Data capabilities [14-16]. However, all these studies require systematization and critical re-thinking, thus constituting the topic of the present article.

Increasing attention paid to taxation issues in terms of industrial revolution resulted from the fact that taxation and production technologies are in a dialectical and interdependent relation. On the one hand, the specific nature of taxes lev- ied at a given place and given period of time is determined by the development level of technologies and those economic institutions formed on their basis. In order to levy a tax, there must be an object capable of being uniquely identified and quantified. In times of dominant agrarian and handcrafting technologies of pre-industrial societies and their corresponding institutions, it was relatively easy to identify and quantify the population, property (land, buildings, animals, etc.) and goods for the purposes of taxation. These comprised the objects for imposing poll taxes, real taxes on certain types of property, excise taxes and duties on goods.

Income became an object of taxation during times of domination of technology overt mass manufacturing at enterprises formed as legal entities, obliged to keep accounts and to maintain public records, including those relating to the income of personnel, the reliability of which could be confirmed by independent auditors. At this point, the concept of taxing the income of individuals and legal entities started to become increasingly widespread. Subsequently, the development of new communication technologies, the international division of labour and global value chains led to the emergence of VAT, which is imposed along these chains and facilitates international settlements.

Currently, in the age of ICT, in which exponential increases in productivity are facilitated [17], digitalized cyber-physical manufacturing generates new assets and objects (digital) and transforms existing ones, leading inevitably to significant changes in tax systems, which arise and quickly spread worldwide (Figure 1). 


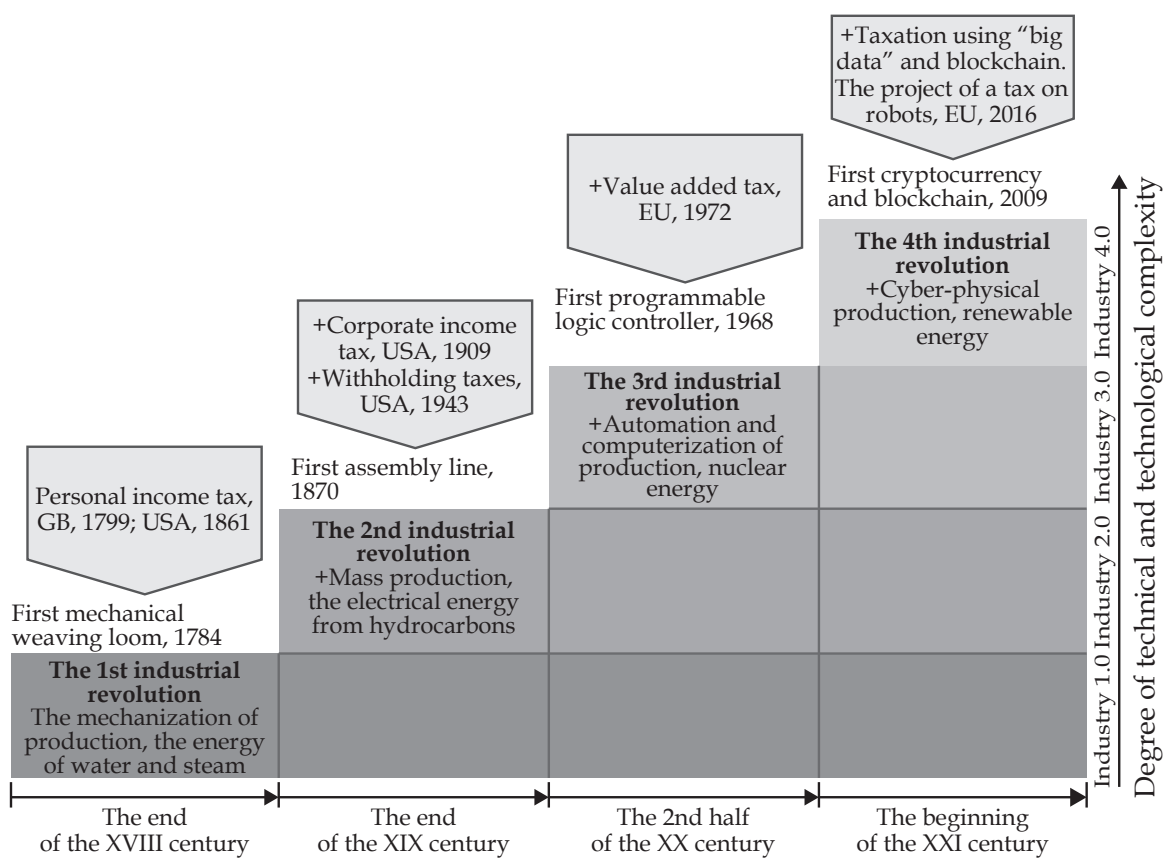

Figure 1. Interconnection of industrial revolutions and taxes

According to the IMF experts: "By transforming the way countries collect, process, and act on information, digital technology can reshape the way governments design and implement their tax, spending, and macro-fiscal policies" [18, p. vii].

On the other hand, taxes themselves and public expenditures financed at their expense predetermine the accelerated development of production technologies and economic institutions. Taxation significantly affects people's behaviour and the activities of the enterprises they create, correcting negative externalities and accumulating resources which may be used to finance public and quasi-public goods, the development of science, human and physical capital, infrastructure, including digital infrastructure, etc. It is sufficient to note that the expenditures on $R \& D$, a significant part of which is financed by taxes, increased globally from $\$ 1$ trillion in 2000 (Constant 2010 US \$) to $\$ 1,7$ trillion in $2015^{1}$.

${ }^{1}$ The World Bank. World Development Indicators. Available at: http://databank.worldbank.org/data/reports.aspx? source $=$ world-development-indicators\#.

\section{Key areas where taxes meet cyber-physical technologies}

The analysis of the results of researches on the transformation of taxation in the context of the new industrial revolution, as well as the main technical and technological features of the cyber-physical systems [19-21], allowed the main directions of the expected changes in the economy and taxation to be determined (Table).

It should only be noted that, since new technologies appear and develop very rapidly under the conditions of the contemporary industrial revolution, the provisions presented therein are a priori incomplete. For example, although until recently, artificial intelligence was in the realm of science fiction, participants in the Beneficial AI 2017 conference have already developed and adopted a list of 23 basic principles that should be followed when developing it ${ }^{2}$. Fifty years ago, the first industrial robot was manufactured; today the issues of interaction of robots in a challenging environment and problems

${ }^{2}$ Future of Life Institute. AI Principles. Future of Life Institute, 2017. Available at: https:// futureoflife.org/ai-principles/. 


\section{Interconnection between technological and tax transformations in the Fourth Industrial Revolution}

\begin{tabular}{|c|c|c|c|}
\hline \multirow{2}{*}{$\begin{array}{c}\text { Technological } \\
\text { changes }\end{array}$} & \multicolumn{2}{|c|}{ Implications } & \multirow[t]{2}{*}{ Possible tax policy measures } \\
\hline & economic & $\operatorname{tax}$ & \\
\hline \multirow[t]{4}{*}{ Digitalization } & $\begin{array}{l}\text { Growth in sales of } \\
\text { digital goods and } \\
\text { services }\end{array}$ & \begin{tabular}{|l|} 
Reduction in taxation base \\
due to cheap digital prod- \\
ucts, reducing amount of \\
taxes on sales and consump- \\
tion of conventional (non- \\
digital) goods and services
\end{tabular} & $\begin{array}{l}\text { Introduction of special taxes } \\
\text { on sales and/or consumption } \\
\text { of digital goods and services, } \\
\text { and/or raising employment } \\
\text { and real taxes (on property, } \\
\text { electric power transmission, } \\
\text { etc.) }\end{array}$ \\
\hline & $\begin{array}{l}\text { Growth in sales } \\
\text { of digital labelled } \\
\text { goods }\end{array}$ & $\begin{array}{l}\text { Expansion of the tax base } \\
\text { due to better control over } \\
\text { the production and products } \\
\text { sales, a reduction in the } \\
\text { "shadow" turnover }\end{array}$ & $\begin{array}{l}\text { Introduction of digital labelling } \\
\text { and its usage in tax adminis- } \\
\text { tration, including for forming } \\
\text { the international registries of } \\
\text { information on unified means } \\
\text { of goods labelling identification }\end{array}$ \\
\hline & $\begin{array}{l}\text { Growth in volumes } \\
\text { of cross-border } \\
\text { online transactions }\end{array}$ & $\begin{array}{l}\text { Taxation base erosion due to } \\
\text { increasing amount of "state- } \\
\text { less" incomes and operations } \\
\text { with affiliated parties in low- } \\
\text { tax jurisdictions, and due to } \\
\text { using of specific contractual } \\
\text { payments and the imposition } \\
\text { of holding companies }\end{array}$ & $\begin{array}{l}\text { Development of international } \\
\text { measures to counteract e- } \\
\text { strategies of tax evasion (incl. } \\
\text { through transfer pricing), } \\
\text { which use the loopholes and } \\
\text { inconsistencies in tax regula- } \\
\text { tion of different jurisdictions }\end{array}$ \\
\hline & $\begin{array}{l}\text { Exponential } \\
\text { growth in volumes } \\
\text { of generated and } \\
\text { used data (Big } \\
\text { Data) }\end{array}$ & \begin{tabular}{|l|} 
Emergence of new oppor- \\
tunities and risks related \\
to use of Big Data in tax \\
administration. Extension \\
of taxation base owing to \\
digital data
\end{tabular} & $\begin{array}{l}\text { Use of Big Data to increase } \\
\text { tax revenues and improve } \\
\text { taxpayer services. } \\
\text { Introduction of a tax on per- } \\
\text { sonal data collection and use }\end{array}$ \\
\hline \multirow[t]{2}{*}{$\begin{array}{l}\text { Robotization } \\
\text { and M2M }\end{array}$} & $\begin{array}{l}\text { Reduction in num- } \\
\text { ber of under- and } \\
\text { semiskilled jobs, } \\
\text { STEM-personnel } \\
\text { shortages }\end{array}$ & $\begin{array}{l}\text { Necessity of compensating } \\
\text { the social tax losses to the } \\
\text { budget due to the reduction } \\
\text { of under- and semiskilled } \\
\text { jobs }\end{array}$ & $\begin{array}{l}\text { Determination of the need and } \\
\text { possibility of introducing new } \\
\text { forms of compensating taxes: } \\
\text { robot taxes, universal basic } \\
\text { dividends, etc. Provision of tax } \\
\text { incentives for retraining and } \\
\text { advanced training of personnel }\end{array}$ \\
\hline & $\begin{array}{l}\text { Increased wealth } \\
\text { disparity }\end{array}$ & $\begin{array}{l}\text { Increased importance of tax } \\
\text { regulation in the sphere of } \\
\text { income inequality }\end{array}$ & $\begin{array}{l}\text { Increased progressivity of the } \\
\text { tax system }\end{array}$ \\
\hline \multirow[t]{2}{*}{$\begin{array}{l}\text { Development } \\
\text { of blockchain } \\
\text { technologies }\end{array}$} & $\begin{array}{l}\text { Growth in the } \\
\text { emission volume } \\
\text { and the areas of the } \\
\text { crypto-currencies } \\
\text { usage, which are } \\
\text { out of the regulato- } \\
\text { ry scope of national } \\
\text { banks }\end{array}$ & $\begin{array}{l}\text { Increased complexity of } \\
\text { the tax administration and } \\
\text { the transformation of the } \\
\text { tax base due to increasing } \\
\text { number of cryptocurrency } \\
\text { transactions and token emis- } \\
\text { sion }\end{array}$ & $\begin{array}{l}\text { Possible introduction of special } \\
\text { taxes on cryptocurrency min- } \\
\text { ing, buying and selling, Initial } \\
\text { Coin Offering }\end{array}$ \\
\hline & $\begin{array}{l}\text { Transparency of } \\
\text { operations, online } \\
\text { access to transac- } \\
\text { tion data, safe and } \\
\text { reliable real-time } \\
\text { transaction record- } \\
\text { ing (worldwide } \\
\text { ledger) }\end{array}$ & $\begin{array}{l}\text { New opportunities of im- } \\
\text { proving tax administration. } \\
\text { Opportunities and risks of } \\
\text { fundamental changes in the } \\
\text { tax system based on decen- } \\
\text { tralized transactions record- } \\
\text { ing, online tax calculations } \\
\text { and payments }\end{array}$ & $\begin{array}{l}\text { Determination of the need and } \\
\text { possibility for using blockchain } \\
\text { technologies for transactions } \\
\text { recording, automatic calcula- } \\
\text { tion and collection of taxes. } \\
\text { Possible shift from the current } \\
\text { tax system based on the com- } \\
\text { parison of income and costs } \\
\text { for the reporting period, to a } \\
\text { system based on the real-time } \\
\text { accounting of income and costs }\end{array}$ \\
\hline
\end{tabular}


related to robots' ability to teach themselves are being studied [22]. In 2009, the first Bitcoins were generated [23, p. vii]; as of 31 December 2017, their market capitalization already exceeded $\$ 200$ billion.

Consequently, we provide a more detailed analysis of only the main points presented in the table, which we consider to be the most important, although many other tax aspects of the development of the digital economy and cyber-physical systems may be equally interesting research directions.

\section{Digitalization}

The many of modern scientific and technological advances, which drastically change our ways of living (mobile internet, automation of knowledge work, the Internet of Things, cloud technology, advanced robotics, autonomous and near-autonomous vehicles, etc. [24]) are based on digital technologies, which in turn were based (technically) on representing the signals as discrete frequencies of analogue levels (but not the continuous spectrum); thus, digitalization consists in the conversion of this information into digital form. In public finance, these technologies mostly affect the spheres of G\&S taxation, cross-border online-transactions and use of Big Data.

Taxes on digital goods and services. Digital transformations in the global economy, related to converting information into a digital form, are very active, but unevenly spread. This is true for both digital tech- nologies and products. These products include digital goods and services ${ }^{3}$, which exist in intangible forms, as well as physical goods with digital labelling.

Some innovative companies already widely use digital technologies at all stages of the product life cycle - from development to technical maintenance, while others are still only investigating the benefits and costs of implementing them. Nevertheless, almost all enterprises use Internet environment for marketing their products and services, both in digital and material form, such that volumes of e-commerce are increasing at a rapid pace (Figure 2).

It is therefore relevant to identify those companies using digitalization for introduction of Industry 4.0 technologies. According to PricewaterhouseCoopers, the companies they surveyed, which combine investments and advanced digitization, plan to cut the costs by $3.6 \%$ for 5 years and annually increase revenues by $2.9 \%[6$, p. 4].

From the taxation standpoint, such digital transformations can be seen positively since an increase in business revenue may increase tax revenues. However, as noted by the experts from the Finnish innovation fund Sitra [25], digital goods can also reduce the tax base. There are several rea-

${ }^{3}$ The term "digital goods" or "e-goods" usually refers to the intangible goods that exist in digital form, and the term "digital services" usually refers to the electronic delivery of information including data and content across multiple platforms and devices.

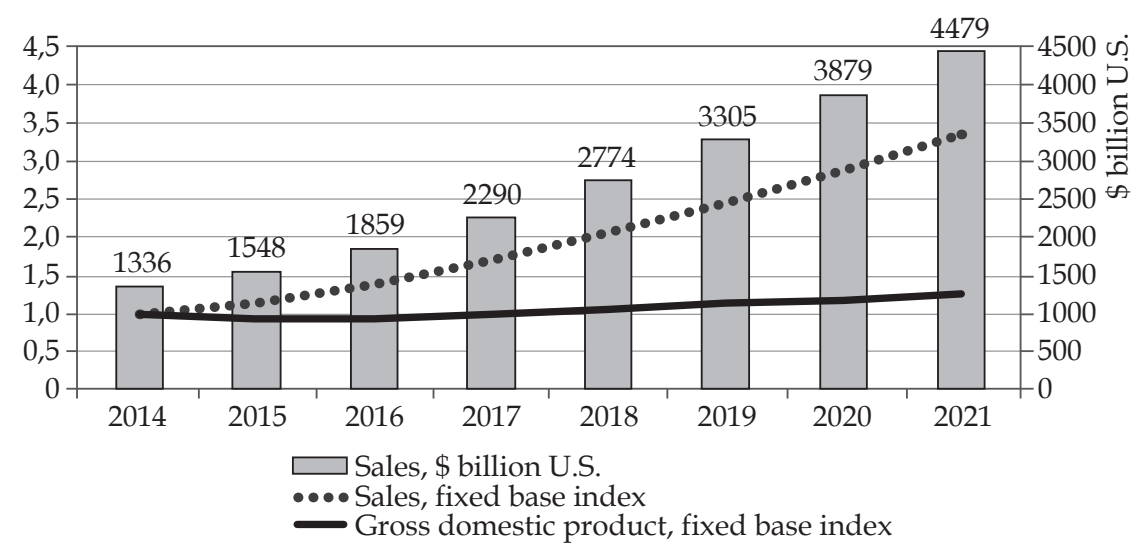

Figure 2. Retail e-commerce sales worldwide and global GDP from 2014 to 2021 Compiled from: Statista.com. (2018); Imf.org. (2018) 
sons for that: first, the cost of digital goods is usually different from that of their physical originals (for example, digital books are cheaper than paperbacks [26]); second, the payment for digital goods and services may be not monetary, but in various forms of barter (subscription to advertising, distribution of various digital products, etc.); third, due to the growth of cross-border trade through the Internet, part of the income of economic entities is being left out of the national tax legislation.

Therefore, in not relying on the passive expectation of the growth of tax revenues from trade in digital goods and services, some countries have been already reviewing their tax systems from the perspective of adapting them to conditions of total digitalization, which opens up wide access for IT-companies to domestic markets.

Following legal proceedings on issues of tax evasion involving such digital monsters as Google, Facebook and Amazon [27], the European Union started working on the protection of tax systems and minimization of the risks of digital companies and platforms not meeting their tax liabilities. One of the possible solutions is the use of special taxes, which close the loopholes for digital business (for example, a turnover tax on all untaxed or insufficiently taxed income generated from Internetbased business activities and a withholding tax on payments made for goods or services online) [28]. Alternatively, one can initially refrain from trying to capture income from digital assets in the "tax net", but instead focus more on tangible assets (for example, on property or electric power transmission), or even switch to taxation in kind (for example, in robotics, or the capacities of server rooms) [25].

A number of countries have already introduced special provisions into their tax codes concerning the taxation of the digital goods and services imports at the location of the customers. Thus, e.g. in Australia, all digital goods and services provided by foreign companies have been subjected to an indirect Goods and Services Tax of $10 \%$ since 2017; in New Zealand, the tax rate is $15 \%$; the Japanese Consumption Tax is $8 \%$; VAT in Taiwan is $5 \%^{4}$. The EU suppliers of digital goods and services pay VAT in the buyer's country at the rate established by national legislation. Russia also introduced a "Google tax" in the form of value-added tax on digital goods and services sold online by foreign IT-companies [29].

Taxes on digitally labelled goods. One of the latest tools employed in the fight against tax evasion and shadow commodity circulation is digital (smart) labelling. The total labelling of goods using digital technologies is assumed to reduce the number of counterfeits, protect business and consumers and increase tax revenues [30]. Another reason for the rapid spread of smart labelling was the growing demand of consumers for transparency of data on products - from manufacturing to purchasing.

IoT (Internet of Things) technologies, which have been used for many years in aircraft manufacture, medicine, and power industry, are used to track data on the functioning of devices and equipment in real time. However, it was only with the development of the smart industry that there appeared a need for developing smart labelling of consumer goods as an effective tool for providing real-time information about the product's authenticity, its location, storage conditions, relocation, etc. [31].

Using the latest technologies, including blockchain, smart labels can provide interested parties with information about the entire supply chain - from the supplier to the end consumer, accumulating data and providing brand protection and safety of product consumption. With the help of mobile devices (smartphones, tablets, etc.), the consumer receives all the information about the product provided by the manufacturer [32].

Naturally, the introduction of digital marking technologies is also associated with certain challenges and risks, including taxation. This concerns the increase in administrative costs for the formation of information resources for the labelling of

${ }^{4}$ SurveyMonkey. Taxes on SurveyMonkey Purchases. help.surveymonkey.com, 2018. Available at: https://help.surveymonkey.com/articles/ru/kb/Taxes. 
goods, unified international approaches to the means of identification ${ }^{5}$, the training and remuneration of the personnel for working with producers, as well as the costs of the producers themselves, the transfer of information to unified registries, etc. Hence the increasing product values, the risks of negative economic consequences, especially for small businesses and the emergence of new schemes of corruption.

Taxes in cross-border online-transactions. One of the key characteristics of the digital economy is increased cross-border business activity, which appears in regard to "... (i) the intangibles on which the digital economy relies heavily, (ii) users, and (iii) business functions as a consequence of the decreased need for local personnel to perform certain functions as well as the flexibility in many cases to choose the location of servers and other resources" [33, pp. 33-34].

This has important tax consequences, for several reasons.

First, the subjects of the digital economy are often located outside the jurisdictions of the national tax authorities. In the case of operating the cross-border online transactions which do not require their physical presence in the country, the incomes of such entities are usually not subjected to its legislation (the phenomenon of "stateless income" ${ }^{\prime}$ ) [35, p. 7].

Second, the enterprises can use transfer pricing to reduce their tax liabilities. This is the case when digital assets from certain tax jurisdiction are transferred to the affiliated parties operating under the lower tax regimes of other countries.

Third, the transition from traditional forms of trade to new ones based on digital

5 Eurasian Economic Commission. Labelling System to Ensure Control over Circulation of Goods within the EAEU. Eurasiancommission.org, 2018. Available at: http://www. eurasiancommission.org/en/nae/news/Pages/6-02-2018-1.aspx.

${ }^{6}$ Edward Kleinbard (the University of Southern California), one of the authors of "Stateless income" concept, points out that such income "... can be understood as the movement of taxable income within a multinational group from high-tax to low-tax source countries without shifting the location of externally-supplied capital or activities involving third parties" [34, p. 703]. platforms affects the ability of tax authorities to levy taxes based on sales and financial transactions (corporate income tax, VAT, etc.). The taxation base, determined by the activities of digital platforms, is narrowed both because of the emergence of "stateless income" and because the use of personal data uploaded by users does not result in financial transactions [36, p. 15].

At the same time, it is important to take into account that modern digital technologies allow foreign operations to be carried out not only by and between large transnational companies, which are always "in sight", but also to numerous small enterprises comprising parts of value chains, which unite the development of digital products and material production. According to the Deloitte experts [37, p. 5], taxation in such chains can be relatively simple if the intellectual property is developed in one jurisdiction (country) and licensed in another. Then, according to transfer pricing rules, production units must pay a fair market price for an intangible digital asset. However, in the case of the uniqueness of such an asset, it is very difficult to accurately determine this price. In addition, it is always possible to come up with special schemes for minimizing taxes, for example, by using cost-contribution arrangements (see "E-commerce structure using a two-tiered structure and transfer of intangibles under a cost-contribution arrangement" [38, pp. 74-76] or "Transfer of manufacturing operations together with a transfer of supporting intangibles under a cost-contribution arrangement" [38, pp. 76-79]).

The problem becomes even more complex if, for example, a smart link is established between the information centre in one territory and the factory floor sensors in another. Traditional transfer pricing models developed for intellectual property licensing cases may not be automatically transferred to other cases, such as smart-linked factories [37, p. 5].

To address these and some other problems, the OECD adopted the Action Plan on Base Erosion and Profit Shifting (BEPS). This refers to instruments of "soft law" that are not legally binding but can 
be used in countries who have common requirements in this field [39]. According to experts from PWC, the implementation of the Action Plan introduces the most significant changes to the system of international taxation in the last 30 years [40].

The Action 1 report [41] is specifically dedicated to mitigating tax problems arising from the digital economy. This final report includes an overview of the principles underlying corporate income taxes and VAT in the context of both domestic law and international tax treaties, the analysis of information and communication technologies and their impact on the economy, recommendations for solving tax problems of cross-border incomes on the basis of CFC (Controlled Foreign Capital) rules, double taxation in cross-border income distribution and the taxation of PE's (Permanent Establishments) under tax treaties.

However, it is already clear that the presented Action Plan needs further improvement. For example, the conceptual provisions for creating value in the digital business that underpin the transfer pricing rules [34, pp. 41-42] and the rules of taxation applying to royalties [42] require further clarification.

Taxation and Big Data. The development of the digital economy and cyber-physical production systems is associated with the real-time processing of huge volumes of information - the so-called Big Data [43]. As noted in the article [44, p. 654], the name "Big Data" refers to a new generation of technologies and architectures designed to derive economic benefits from very large volumes of a wide range of data, through their high-speed capture, detection and/ or analysis. This definition describes four distinctive features of big data: volume, variety, velocity and value. As a result, the definition of " $4 \mathrm{Vs}$ " is widely used to characterize big data.

It is important to note that the volumes of data being generated and accumulated in the world are growing exponentially: during 1970s-80s from kilobytes ( $2^{10}$ bytes) and megabytes $\left(2^{10} \cdot 2^{10}\right.$ bytes $)$ to gigabytes $\left(2^{10} \cdot 2^{10} \cdot 2^{10}\right.$ bytes); during the 1980s-90s from gigabytes to terabytes $\left(2^{10} \cdot 2^{10} \cdot 2^{10} \cdot 2^{10}\right.$ bytes); during the 1990s-2000s from tera- bytes to petabytes $\left(2^{10} \cdot 2^{10} \cdot 2^{10} \cdot 2^{10} \cdot 2^{10}\right.$ bytes); and at the present time from petabytes to exabytes $\left(2^{10} \cdot 2^{10} \cdot 2^{10} \cdot 2^{10} \cdot 2^{10} \cdot 2^{10}\right.$ bytes $)$.

The tax authorities of many countries have already realized the importance of Big Data technologies for solving the tasks assigned to them [45]. They offer ample opportunities for using the newest methods of data storage and processing by tax authorities, as well as automation of their basic functions, which will allow them to reduce routine operations and focus on solving the most important tasks: improving the practice of tax audits based on the development of databases on compliance with tax legislation; more accurate planning of tax revenues and liabilities; improving the effectiveness of the fight against tax fraud and tax evasion by better identifying and assessing risks; improving the auditability and accuracy of regulatory reporting [46].

In general, as the OECD specialists note [15, p. 102], the Big Data technologies providing improved access to data in realtime or near-real-time, as well as the ability to combine data and analytics, open new perspectives for tax authorities - on the one hand, to increase tax revenues and, on the other hand, to improve the support of taxpayers in fulfilling their tax obligations, promote tax compliance, reduce the taxpayers burden and increase the level of their trust.

At the same time, security risks, breaches of confidentiality and intellectual property rights are simultaneously increasing. The use of Big Data objectively creates a wide field for the growth of various kinds of offenses and crimes ${ }^{7}$. Therefore, the issues of preventing leakages and maintaining the integrity of their data, protection of intellectual property rights rise for enterprises, as well as issues of privacy, protection of personal and family secrets and the use of information to ma-

\footnotetext{
${ }^{7}$ According to estimates of the Cybersecurity Ventures, cybercrime will cost the world \$6 trillion annually to 2021, compared to $\$ 3$ trillion in 2015. This is the largest transfer of economic benefits in history that undermines incentives for innovation and investment and will be a more profitable business than, for example, global trade of all major illicit drugs combined [47].
} 
nipulate behaviour, are exacerbated for people generally [48, pp. 105-106].

In this regard, it is important to emphasize that the personal data provided, for example, by users of social networks, are an asset that can generate income [49]. As users of these networks, people actually pay for access to communication not generally with money, but rather with information. Then there are the companies specializing in the collection, processing and sale of this information, for example, to provide credit scores for borrowers ${ }^{8}$. Obviously, commercial enterprises should not be the sole beneficiary of these financial benefits (since market distortions will arise as a consequence). Instead, these revenues should be shared with the wider society and used to adjust externalities; for example, to create a more socially just and responsible Internet.

Various fiscal instruments can be used to address this problem, for example, a small tax (e.g. less than $1 \%$, so as not to create large distortions in the behaviour of economic agents) on the income of companies from the sale of personal data [51]. France has already tried introducing a personal data collection tax: a pilot reform was represented in the form of the tax upon the biggest contributors (only above a certain threshold in the number of users) in the form of a single tariff per user, which could vary according to the behaviour of the business (e.g. compliance towards data protection, data security and data portability) [52]. However, for various reasons, it has not yet been implemented.

${ }^{8}$ This can lead, among other things, to the emergence of a conflict of interest. Here it is possible to refer to one of the latest examples from the Russian economy. The Double Data company, which specializes in the development of software for analyzing Big Data, collected information about users of the social network VKontakte: names, places of work and study and other open information, and then used it for commercial purposes (selling the received data to banks, which, in turn, used the information to assess the creditworthiness of borrowers). VKontakte filed a lawsuit against this company. The Arbitration Court of Appeal granted the claim in part and banned the collection and analysis of information about users of the social network for commercial purposes [50].

\section{Robotization and M2M}

The Fourth Industrial Revolution has led to the acceleration of processes of automation and robotization, especially in such areas as robotic human augmentation and the use of industrial robots [24, p. 73]. Over the past few decades, industrial robots have taken over many production tasks, especially those which are difficult, dangerous or impractical for humans. Recent scientific and technological achievements have led to robots carrying out an increasingly wide range of tasks which were once considered the prerogative of human, for example, picking and packing or manipulating small electronics parts [24, p. 68]. Moreover, M2M (machine-to-machine) technologies which allow machines to exchange information and perform actions without human help, are also becoming more common. This leads to a simultaneous reduction in production costs and an accelerated growth in the production of robots worldwide (Figure 3).

Compiled from: Statista.com. (2018). Such technical and technological innovations can lead to profound transformations in the labour market. According to McKinsey Global Institute estimates, $30 \%$ of the constituent work activities of $60 \%$ of current jobs are capable of being automated. It is anticipated that by 2030, 75-375 million current employees (from 3 to $14 \%$ of their total number) will have been forced to change their professional categories. In addition, all employees will need to upgrade their skills to adapt to new working conditions in cooperation with robots [53, p. ii]. Under such conditions, the base for labour taxes can be significantly narrowed and the paradox of plenty will arise, in which the society at large becomes richer, but income and/or property stratification grows, and the situation worsens for the majority.

In order to avoid such an unfavourable scenario, additional tax regulation aimed at correcting the negative externalities of robotics and M2M processes is required. For this purpose, traditional tax instruments can be used alongside new ones, which are only presently being discussed, but already attracting attention and causing heated discussions, can be used. 


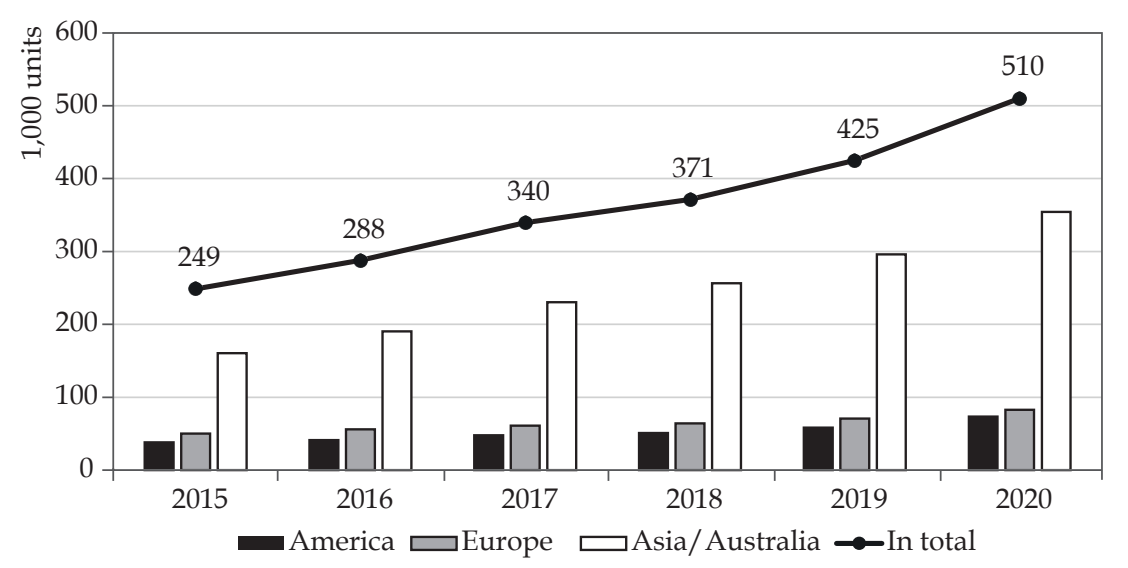

Figure 3. Estimated annual industrial robot shipments in selected regions worldwide

Taxes on robots. A robot tax - or, more precisely, a tax on using robots for the automation of production - has until recently only been a futuristic hypothesis. However, already in 2016, the European Parliament working report, prepared by the Committee on Legal Affairs, put forward the idea of such tax. One of the arguments for this tax involved the concern about the future employment of the population and the viability of social security systems if the current taxable base is to be maintained in the law, thus laying the ground for increasing inequality in the distribution of wealth and influence [54, p. 3].

One of the main ideas of the report is to grant "... a specific legal status for robots, so that at least the most sophisticated autonomous robots could be established as having the status of electronic persons with specific rights and obligations, including that of making good any damage they may cause, and applying electronic personality to cases where robots make smart autonomous decisions or otherwise interact with third parties independently" [54, p. 12]. This is evidently a very unusual and controversial idea, which has both supporters and detractors [4, p. 248].

Anyway, endowing robots with such a specific legal identity implies an acknowledgement of the phenomenon of electronic paying capacity to be used for taxation. In particular, it can be taxes on imputed wages or on income received from the activities of robots (such that the tax is being levied not on a robot as such, but rather on the use of robots). Moreover, since robots can sell goods or provide services, they also potentially comprise an object for VAT [4, p. 254].

The idea of imposing a robot tax got the support of Microsoft founder Bill Gates [55]. Therefore, this fiscal instrument is sometimes referred to as the "Bill Gates Robot Tax". According to the Nobel laureate R. Shiller [5], robot taxes could slow down the processes of rapid robotization (at least for a while) as well as ensuring the receipt of income necessary for financing retraining programs for redundant workers.

In August 2017, The Korea Times published an article entitled "Korea takes first step to introduce 'robot tax'" [56]. It noted that the government, within the framework of the proposed revision of the tax legislation, would introduce the restrictions on providing tax incentives for investments in the automation of production by the end of the year. These restrictions were aimed at compensating for the loss of income tax and providing social payments to dismissed workers who had been replaced by robots. Although it is impossible to directly refer to this fiscal instrument as a robot tax, nevertheless they share the same goal that is to reduce the loss of state revenues due to the robotization of production and to cut the labour tax base.

Around the same time, in California, the "Jobs of the Future" fund was created 
alongside a campaign for introducing robot taxes in response to the fear that they would gradually completely replace human labour [57]. The main objective of the fund was to study the state of the tax system in the process of changes in the labour market and to develop countermeasures ("pay-roll" tax on job-stealing machines), to make future M2M more comfortable for people.

Naturally, the idea of a robot tax meets with considerable opposition. The main stated objection is that it will interfere with innovation. From this point of view, taking into account global problems of productivity growth and sustainable development, there are not too many robots, but too little: the taxation of new technologies is not the best, but the worst solution. Here it is important to take into account the fact that the robot tax is a tax on capital that not only contradicts the theory of optimal taxation but will introduce additional distortions in connection with various tax regimes with respect to robots in individual countries. It is equally important from the fiscal point of view that the obvious problems of determining what a "robot" is for tax purposes can in practice turn this tax into a logical and legal nightmare [58].

Universal basic dividends and progressive income redistribution. The vulnerabilities of the idea of introducing a robot tax stimulate the search for other approaches to solving the problem of robotics and M2M. For example, the former Minister of Finance of Greece, Y. Varoufakis [59], who considers that the fundamental disadvantage of this tax is the complexity of defining the term "robots" and their imputed income, sees the way out in the redistribution of return on capital through the creation of a state trust.

The purpose of such a trust would be to receive the so-called universal basic dividend (UBD), paid out at the expense of return on the entire capital of the enterprise, which is the paraphrase of the known idea of unconditional basic income. For this purpose, according to the author, it is necessary to adopt a special law requiring the transfer of a certain percentage of corporate shares at each initial public offering (IPO) into a Commons Capital Depository (in fact, this will be the law on the tax-in-kind on the IPO), and to finance the payment of a UBD at the expense of the stock dividends [60]. If this proposal is implemented, then the increase in the production robotization and automation will result in an increase in the incomes of enterprises and an automatic redistribution of profits to the solution of social problems will take place through the state trust that owns a part of their shares.

A similar idea, put forward earlier by the American economist M. Kimball (an economics professor at the University of Michigan), entailed the creation of a sovereign wealth fund [61]. However, the source of financing of its assets, according to M. Kimball, should not be the forced transfer of a part of the securities issued to the state trust, but rather the current tax revenues, which are being used for purchasing shares and real estate with subsequent distribution of profits to the population. This approach will also allow part of the revenues generated by robots to be redistributed, giving each citizen his or her share in the new cyberphysical economy. In addition, in order to avoid undesirable concentration of property, the sovereign wealth fund can be divided into several small parts, each having different managers.

However, it is easy to notice that, ultimately, we are talking about different forms of income redistribution in a society, whose economic growth is dependent on the replacement of labour with capital. For this purpose, it is also possible to use traditional time-proven tools.

More simple and traditional solutions to the undesirable socio-economic consequences of robotization and M2M are, for instance, the greater degree of progressiveness of certain forms of corporate profit taxation and increases in property taxes, combined with the financing of assistance programs for those who lose out from robotics. However, it should be kept in mind that progressive income taxation contradicts the principles of optimal taxation and can introduce additional distor- 
tions in the behaviour of economic entities, leading to losses in public welfare.

The proposal to subsidize the wages of workers with low incomes serves the same goal. The simplest way to do this is to reduce payroll taxes that disproportionately burden the low-wage workers [62]. This will mean financing a part of national, regional and local programmes from other sources of income, such as higher taxes on income and wealth and/ or value-added tax.

Finally, the previously discussed measures of preventing the tax evasion from capital income through transfer pricing and the use of tax havens (the BEPS action plan) can be included here.

\section{Tax implications of blockchain technologies}

Blockchain technologies or distributed ledger technologies are considered to be one of the breakthrough inventions of the 21 st century. They have the potential to dramatically transform much of what we now know and do, as well as how we do it [63]. From an engineering point of view, blockchain is a digital technology as well. Additionally, perhaps, it would be logical to discuss it among the problems of taxation in the digital economy, for example, in conjunction with the taxation of digital goods and services. In this article, however, distributed ledger technologies are allocated to a special sector, since their sphere of influence goes beyond the usual digital economic problems. Although blockchain technologies have the potential to restructure many significant aspects of the development of society on the principles of decentralization, the successful implementation of such approaches is another matter. Nevertheless, it is already possible to make some preliminary conclusions regarding the taxation of cryptocurrencies and new far-reaching principles for reconstructing the tax system as a whole.

Taxes on cryptocurrencies. Cryptocurrencies, in the usual sense, are cryptographically protected digital assets, serving as an exchange medium. They use blockchain technologies to control emissions, protect transactions and verify the transfer of assets. Their popularity is largely due by the fact that, unlike conventional national currencies, they are not regulated by banking regulators and do not have an issuing centre.

Despite the sharp volatility of major cryptocurrencies, which is caused, among other things, by the actions of a large number of non-professional speculators, the volumes of the transactions denominated in cryptocurrencies are growing rapidly. For example, global Bitcoin transactions grew approximately 100-fold in 2017 alone - from $\$ 300$ million a day at the end of December 2016 to near $\$ 4$ billion a day at the end of December $2017^{9}$. Although this is still a very small number compared to the volumes of transactions in fiat currencies, the tax authorities of different countries are already naturally raising questions about tax regulation in this connection.

Unified approaches have not yet been developed. The legislation determining the legal status of the cryptocurrencies and their taxation is in the process of formation [64; 65]. A generalization of the taxation practice of individual countries shows that, in this sphere, either a variety of legal approaches and different taxes (income tax, capital gains tax, VAT) are being applied, or the issue is being largely neglected.

For example, the US Internal Revenue Service (IRS) considers crypto-currencies to be a property. This implies that crypto investments fall under the capital gains tax with different rates depending on the duration of the period during which the business entity owned the crypto currency (before receiving the profit). In neighbouring Canada, cryptocurrencies are recognized as commodities; accordingly, rules governing the imposition of business income tax or capital gain tax are applied to them.

In the EU, the taxation of cryptocurrencies and operations with them is carried out in accordance with the national legislations of member states. The excep-

${ }^{9}$ Quandl.com. Bitcoin Estimated Transaction Volume USD. Quandl, 2018. Available at: https:// www.quandl.com/data/BCHAIN/ETRVU-Bitcoin-Estimated-Transaction-Volume-USD. 
tion is value added tax, since in 2015 the European Court of Justice has decided that the operations of the Bitcoin purchasing and selling for traditional fiat currencies are not subject to this tax [64, p. 34].

In some European countries the situation is as follows. The United Kingdom (UK), which does not recognize cryptocurrencies to be legal currencies (as in Canada), either imposes an income tax (for traders) or a capital gains tax (for ordinary investors). At the same time, the so-called "mining" of cryptocurrencies is considered a type of business and is subject to corporate income tax at a standard rate of $20 \%$. In Switzerland, however, Bitcoin was recognized as a "foreign currency" with all the resulting tax consequences [66]. In Germany, at the beginning of 2018, crypto-currencies were recognized as an alternative contractual and immediate means of payment ${ }^{10}$. Thus, digital currencies will not be taxed if they are used as a means of payment. Instead, payment for goods with cryptocurrencies will be subject to VAT at the current exchange rate at the transaction time. However, the actual act of converting cryptocurrency into fiat money or vice versa is classified as "provision of services", so the party acting as an intermediary is not taxed. "Miners" who receive rewards in cryptocurrencies will similarly not be taxed, since their services are considered to be voluntary.

China, which is one of the main global drivers of the modern digital economy, considers cryptocurrency to be a commodity and imposes taxation in accordance with the standard rules for commodities: operations with a cryptocurrency are subject to corporate income tax and capital gains tax; moreover, its sale can be taxed with a value-added tax [64, c. 51].

It should be noted, however, that, in Q3 2017, China banned crypto exchanges and Initial Coin Offerings (ICOs) indefinitely in domestic markets [66], additionally taking measures to minimize mining

10 Digithereum.com. Germany Recognizes Cryptocurrency as a Legal Tender. Digithereum, 2018. Available at: https://digithereum.com/ news/germany-recognizes-cryptocurrency-legal-tender. activity [67], explaining this by the need to reduce financial risks and prevent currency manipulation and tax evasion. Moreover, in March 2018, the governor of the People's Bank of China stated that China does not recognize Bitcoin and other digital currencies as legitimate forms of payment [68].

As for the post-Soviet states, legislation on the status and taxation of cryptocurrencies and their mining is still under development in the Russian Federation [69]. A similar situation is observed in Ukraine [70].

In the field of cryptocurrencies, the phenomenon of the Initial Coin Offering (ICO) is especially worth noting. During an ICO, investors are offered tokens ${ }^{11}$, usually in exchange for already established cryptocurrencies (for example, bitcoins). In fact, this is a new way of using crowdfunding methods to implement innovative projects, allowing a reduction in administrative barriers affecting conventional venture capital financing with all the ensuing advantages (lower transaction costs) and disadvantages (possible abusive activities and fraud).

In the US, for example, in 2017, over $\$ 1$ billion was raised through ICOs [72]. In this country, unlike in traditional methods of capital raising, ICOs cannot apply for tax exemption. At the same time, the amount of taxable income should be determined on the basis of the fair market value of the cryptocurrency received from the ICO on the date it ended [73]. Tokens may also be subject to VAT (in those countries where it is applied). However, according to some experts, this object occurs not on the issue of tokens, but after their subsequent use as a means of payment for specific services offered by a start-up (similar to the VAT on multi-purpose vouchers) [74].

Using blockchain for transforming the taxation system. Taxation is one of those areas

${ }^{11}$ According to W. Mougayar, a token is "... a unit of value that an organization creates to selfgovern its business model, and empower its users to interact with its products, while facilitating the distribution and sharing of rewards and benefits to all of its stakeholders" [71]. The tokens may be the digital counterparts of real (physical) assets or services (asset-backed tokens), and in this case they have little in common with the currency as such. 
of the economy where the application of blockchain technologies can lead to revolutionary changes [75]. The reason for that lies in the following salient characteristics:

- transparency - the blockchain is a distributed database based on ledger algorithms in which all network members can see and verify data [23, p. x]. At the same time, the open, detailed and invariable nature of information in the blockchain system provides a more reliable means of recording economic transactions, ownership transfer, reconciliation of accounts receivable and payable, etc. - a full range of information that may be related to taxation;

- self-checking - a distributed database cannot be altered after entering the data. This makes fraud and errors far easier to detect and reduces the risks of noncompliance with tax laws [76]. The main condition for putting data into a distributed database is the confirmation of their authenticity by all network members. This requirement is the basis for smart contracts $^{12}$, the proper implementation of which does not require control inputs from intermediaries, which in this case are represented by the contracts between the providers of personalized public services and taxpayers [23, c. 44]:

- information in real-time or near realtime - unlike the current approach, when tax charging and mobilization are performed retrospectively, including on the basis of data on incomes and costs for the reporting period, the use of the blockchain system allows the information to be updated simultaneously for all network participants in real time. This makes it possible to use the blockchain to transparently calculate and pay taxes in step with the execution of economic transactions, as they happen [77, pp. 2-3];

- efficiency - using the blockchain can significantly reduce the costs of business and the state. Business-related blockchains

\footnotetext{
${ }^{12}$ Smart contract is a computer algorithm designed to conclude and maintain self-executable contracts in the blockchain environment. They are written in the form of code in a distributed ledger, which is maintained and managed by a network of computers. After the trigger happens, the contract is automatically executed in accordance with its terms.
}

form the worldwide ledger. This ledger can also be used for the purposes of calculating and paying taxes. Its application will help reducing the cost of compiling tax reports, reducing the number of tax inspections and saving government spending on administration and personnel [13, p. 8].

New blockchain opportunities are associated with new risks and threats [78]. Among these are the regulatory risks (gaps in legislation, lack of experience in implementing large-scale blockchain projects in a regulated environment), technical risks (problems with the bandwidth, delays in processing transactions, size and speed of data dissemination, threat of the "51\% Attack"13, the difference between versions and the problem of ensuring the compatibility of multiple chains), the risks of social aversion (in connection with the possibility of using blockchain and cryptocurrencies based on them for criminal purposes), etc. [80; 81].

Considering the blockchain features noted above, its tax implications can have two main directions.

The first direction is to improve tax administration. Already at the present time, blockchain technologies can be useful to the tax authorities, as it provides accurate, detailed and reliable information of wide spectrum that can be shared. This makes it possible to improve the taxation of digitally marked high-value products [32], generally improve and accelerate the charging and collection of taxes related to transactions such as VAT, withholding tax, stamp duties and insurance premium taxes, and to improve the efficiency of combating tax evasion and the quality of services provided to taxpayers [76, p. 2].

The second direction is for the prospective transformation of the tax system with the transition from retrospective tax-

${ }^{13}$ The threat of " $51 \%$ Attack" is embedded in the architecture of the blockchain itself. If a coordinated group of people has under control more than $50 \%$ of the processing power that provides the verification process for transaction logs in the blockchain, such a group will be able not to confirm the other's transaction blocks, but only to confirm its own, which means it will be able to receive all newly issued bitcoins and block at its discretion any transactions [79]. 
ation for the reporting period to the taxation in real-time. If tax administrations have open access to company transactions as they happened, then the state computer programs can immediately calculate the amount of tax and automatically withhold it from the bank account of the company immediately after the transaction settles. Under such a scenario, advance payments will be eliminated, and the functions of the tax departments will be largely replaced by blockchain maintenance, the secure, real-time transaction ledger and related software. Potentially, the incidence of errors and fraud in this sphere thus can be eliminated [77, p. 3].

Of course, this is only a conceptual statement, not a proposal for immediate practical implementation. Given that besides the abovementioned risks and threats, a lot of undecided questions arise: on the location of the transaction for tax purposes (taking into account that in a distributed ledger a transaction is recorded in many places simultaneously and the identity or location of the counterparty may remain unknown); on barter taxation; on determining the taxable value if the transaction occurs in a digital currency; on what element does the VAT have to be accounted for and whether its rate depends on the counterparty location, etc. [75].

In this regard, it is important to understand that the blockchain is one of the new tools for solving the age-old problem of taxation, which allows a fresh look to be taken at it from a new point of view, but not the decision itself.

\section{Conclusions}

In terms of the Fourth Industrial Revolution, emerging and disruptive technologies are developing very quickly. However, these do not merely consist of physical and digital objects combined with ways of interlinking them into production chains. Objects and chains are created by people who themselves change during the interaction, and this eventually leads to the transformation of the system of socio-economic - including fiscal - relations.

Somewhat exaggerating, we can say that taxes are the main attribute of the
State. Taxes mean that the economic actors comply (in a voluntary or forced manner) to authorities and it expresses the consent to execute transactions under the authorities' control and abandon a part of the income (property) in favor of the State. Therefore, if economic transactions are carried out without an external or internal administrator, the subjects of transactions also start to move out of State control. As a result - the State gradually fades away from these economic actors' activity and loses its significance to them

The practice is not so radical yet; hence, nation states (state alliances) which have proven their viability for centuries, have the opportunity to place disruptive technologies, including cyber-physical ones, under their control. However, the paradox remains that the very process of public relations coverage of the sphere of cyber-physical space implies an advance in a direction that "erodes" the conventional taxation base traditionally used by the authorities for centralized control over the activities of economic entities and the financing of public services. This is the one side of it.

The second consequence is the emergence of technologies that create the opportunity to facilitate the mechanism of tax administration (resulting from the replacement of periodic self-reporting of revenue, expenses and taxes owed by real-time recording of public company transactions), which reduces the need for traditional administration, transferring it into an automatic mode of "digital tax administration".

The phenomenon of digital "stateless income" can cause the phenomenon of "stateless residents" and, as a consequence, "taxless" residents (without forced payments), i.e. those residents who receive the services they need, not from the government, but from the network of decentralized and voluntarily funded suppliers [23, p. 44]. When all this concerned only the development of the digital economy (service sector), it was not so important, because the foundation of people's economic lives remains the exchange and consumption of material goods. However, now the "digit" increasingly connects and 
permeates the physical processes, creating global decentralized technologies for carrying out the transactions and hybrid cyber-physical products. In other words, it is not about the goods themselves, but the fact that they are no longer just physical, but cyber-physical (like smartphones, robots, autonomous cars, etc.), resulting in an increasing proportion of their value residing in the digital content. Consequently, the principle of "statelessness" and "taxlessness" is extended at least to a part of the production cost.

There are three main approaches towards a fiscal solution for new problems associated with the development of cyberphysical systems (Figure 4).

The first approach is to try to cover with taxes new cyber-physical technologies and products of their application. Many steps are being taken in this direction, for example, the OECD's 2015 final report on Action 1, which is designed to capture intangible digital assets and generate (primarily cross-border) revenue streams into the state's "tax nets". This also includes the spread of traditional taxes on new subjects - robots (electronic persons), which, figuratively speaking, come to grips with tax inspectors, where the inspectors' side involves the establishment of the rules of the tax game (the tax legislation adjusted for the activities of new subjects), and the robots' side has the artificial intelligence, which has already outstripped human in- telligence in some respects. However, this is a demanding and - apparently - not very promising approach.

The second approach is to replace digital transactions and shortfalls in revenues by traditional objects of taxation in the form of tangible assets and people and / or to increase tax pressure (including through the improvement of tax administration using Big Data) and increase the degree of progressiveness of taxes already levied on such objects. This is technically simpler; however, financial theorists have long argued that, for example, real property taxes are far from being the best way to build a holistic state tax system. Proposals for switching to in-kind taxes are viewed with even more suspicion. As for increasing the degree of progressiveness of labour taxes, this contradicts the theory of optimal taxation and can have undesirable consequences from the standpoint of tax compliance.

The third approach is to set a course towards constructing a new tax space with smart taxes based on real-time principles and smart contracts. This implies the transition to automatic taxation using blockchain technologies, which focus on the functions of applying distributed ledgers of business transactions in real-time with the use of relevant software. However, the paradox is that in time these functions will also be better entrusted to the robots, which will increasingly supervise people

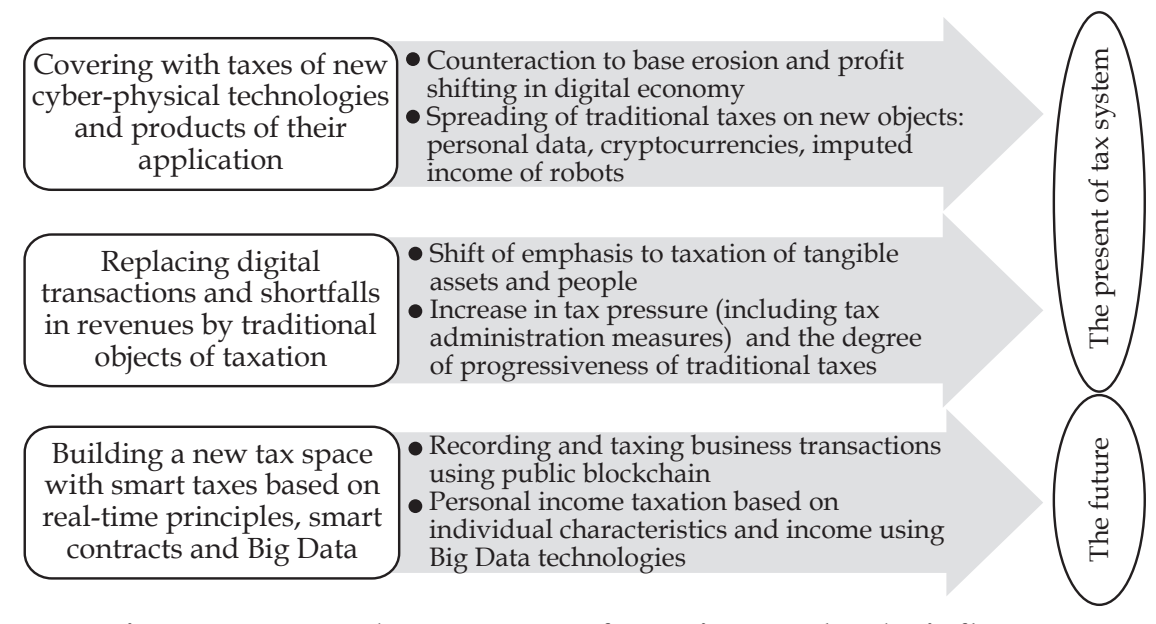

Figure 4. Approaches to tax transformations under the influence of developing cyber-physical technologies 
and other robots. Of course, all this is still somewhat futuristic and there are a lot of obstacles on this path, including those still unknown. However, long-term trends are already visible and, in a certain sense, encouraging. The theory of optimal taxation asserts that the principles of a good tax system are a waiver of capital income tax, the use of flat tax, with a universal lumpsum transfer to all individuals or uniform tax on final goods, and the dependence of taxes on personal characteristics, as well as income [79, p. 147].

While advanced economies are already seeing some progress in this direction, there is a continuing lack of confidence [79, p. 148]. Nevertheless, the situation is changing rapidly. Emerging technologies create a principal possibility for smart realtime taxation. Obviously, from the point of view of automation, this can consist of simple flat obligations such as a universal consumption tax combined with negative taxes, comprising social grants that take into account real incomes and other personal circumstances identified through the use of the Big Data. This implies that, as a consequence of new technologies, the principles of the optimal taxation theory can acquire a new lease of life.

\section{References}

1. Bacache-Beauvallet M., Bloch F. Special issue on taxation in the digital economy. Journal of Public Economic Theory, 2017, vol. 20, iss. 1, pp. 5-8. DOI: 10.1111/jpet.12285.

2. Gupta S., Keen M., Shah A., Verdier G. Reshaping Public Finance. Digital revolutions in public finance. Washington, DC. International Monetary Fund, 2017, pp. 1-21.

3. Crémer J. Taxing Networks Externalities. Taxation and the digital economy: A survey of theoretical models. France Stratégie, Final report, 2015. 16 p.

4. Oberson X. Taxing Robots? From the Emergence of an Electronic Ability to Pay to a Tax on Robots or the Use of Robots. World Tax Journal. 2017, vol. 9, no. 2, pp. 247-261.

5. Shiller R. Robotization Without Taxation? Project Syndicate, 3/26/2017.

6. PwC. Global Industry 4.0 Survey. Industry 4.0: Building the digital enterprise. PwC, $2016.34 \mathrm{p}$.

7. PwC. Government's Many Roles in Fostering Innovation. PricewaterhouseCoopers LLP, 2010. 65 p.

8. PWC. Industry 4.0 and tax incentives. PwC \& TLS Associazione Professionale di Avvocati e Commercialisti, 2017. 4 p.

9. McKinsey Global Institute. Digital Finance for All: Powering Inclusive Growth in Emerging Economies. McKinsey \& Company, 2016. 112 p.

10. Pritchard G., Hatherell D., Young L., Stocker A. When tax meets technology. Deloitte University Press, 2017. 20 p.

11. Deloitte. Making things in a changing world - Industry 4.0 \& Indirect Taxes. Deloitte LLP, 2015. 26 p.

12. EY. Top of Mind. The dawning of digital economy taxation. EYGM Limited. August 2015. 7 p.

13. EY. Blockchain: a chain reaction. Technology company in anticipation of reaching critical mass. Ernst \& Young Global Limited, 2016. 15 p. (In Russ).

14. OECD. Co-operative Tax Compliance: Building Better Tax Control Frameworks. OECD Publishing, Paris, 2016. 34 p. DOI: $\underline{10.1787 / 9789264253384-e n}$.

15. OECD. Technologies for Better Tax Administration: A Practical Guide for Revenue Bodies. OECD Publishing, Paris, 2016. 106 p. DOI: 10.1787/9789264256439-en.

16. OECD. Advanced Analytics for Better Tax Administration: Putting Data to Work. OECD Publishing, Paris, 2016. 57 p. DOI: 10.1787/9789264256453-en.

17. Mack C. The Multiple Lives of Moore's Law. IEEE Spectrum, 2015, vol. 52, iss. 4, pp. 31. DOI: $10.1109 /$ MSPEC.2015.7065415.

18. Gupta S., Keen M., Shah A. Verdier G. (eds). Digital revolutions in public finance. Washington, DC, International Monetary Fund, 2017. 343 p. DOI: 10.5089/9781484315224.071.

19. Chen B., Wan J., Shu L., Li P., Mukherjee M., Yin B. Smart Factory of Industry 4.0: Key Technologies, Application Case, and Challenges. IEEE Access, 2017, vol. 6, pp. 6505-6519. DOI: 10.1109/ACCESS.2017.2783682.

20. Chekina V. Smart Industry and Taxes: common ground. Finance of Ukraine, 2017, no. 11 (264), pp. 89-109. (In Ukrain.)

21. Kniaziev S.I. Development of smart industry as an efficient way to implement the policy of neoindustrialization in the world. Economy of Industry, 2017, no. 4 (80), pp. 5-18. DOI: $\underline{10.15407 / \text { econindustry2017.04.005. }}$. 
22. Orseau L., Armstrong S. Safely Interruptible Agents. UAI'16 Proceedings of the ThirtySecond Conference on Uncertainty in Artificial Intelligence, Jersey City, New Jersey, USA, June 25-29, 2016, pp. 557-566.

23. Swan M. Blockchain. Blueprint for a New Economy. Sebastopol, CA: O’Reilly Media, Inc., 2015. 128 p.

24. Manyika J., Chui M., Bughin J. et al. Disruptive technologies: Advances that will transform life, business, and the global economy. McKinsey Global Institute, 2013. 162 p.

25. Mokka R., Neuvonen A., Lindgren J. Digitalisation and the future of taxation. Sitra, 2017. Available at: https://www.sitra.fi/en/articles/digitalisation-future-taxation/.

26. Belkin N. Study: Russians have tasted e-books. Vesti. Hi-tech, 2017. Available at: https:// hitech.vesti.ru/article/669740/ (In Russ.).

27. Rankin J. EU to find ways to make Google, Facebook and Amazon pay more tax. The Guardian, 2017. Available at: https://www.theguardian.com/business/2017/sep/21/tech-firms-tax-euturnover-google-amazon-apple.

28. European Commission. A Fair and Efficient Tax System in the European Union for the Digital Single Market. Communication from the Commission to the European Parliament and the Council. Brussels, 21.9.2017, COM(2017) 547 final.

29. Sorokina O. "Tax on Google": what is waiting for foreign Internet companies in 2017. Forbes. ru, 2016. Available at: http://www.forbes.ru/kompanii/336337-nalog-na-google-chto-zhdetinostrannye-internet-kompanii-v-2017-godu (In Russ.).

30. Butrin D., Grishina T., Kotova M. Happy new code. Vladimir Putin approved the scheme of continuous marking in the commodity market until 2024. Kommersant.ru, 2017. Available at: https://www.kommersant.ru/doc/3502973 (In Russ.).

31. Kavis M. The Smart Labels That Will Power the Internet of Things. Forbes.com, 2015. Available at: https://www.forbes.com/sites/mike-kavis/2015/02/17/the-smart-labels-that-willpower-the-internet-of-things/\#1863b93b2ba6.

32. Clancy H. Let your product do the talking: the rise of smart labels. GreenBiz. 2016. Available at: https:// www.greenbiz.com/article/let-your-product-do-talking-rise-smart-labels.

33. OECD. BEPS Action 1: Address the Tax Challenges of the Digital Economy. Public Discussion Draft. 24 March 2014 - 14 April 2014. 81 p.

34. Kleinbard E. Stateless Income. Florida Tax Review, 2011, vol. 11 (9), pp. 699-774.

35. Olbert, M. and Spengel, C. International taxation in the digital economy: challenge accepted? World tax journal, 2017, no. 1, pp. 3-46.

36. France Stratégie. Taxation and the digital economy: A survey of theoretical models. Final report. February 26, 2015. 56 p.

37. Pritchard G., Hatherell D., Young L., Stocker A. When tax meets technology. Tax implications of Industry 4.0. Deloitte University Press, 2017. 20 p.

38. OECD. Addressing Base Erosion and Profit Shifting. OECD Publishing, 2013. 87 p. DOI: 10.1787/9789264192744-en.

39. Bykov S., Frotscher G. Anti-Avoidance Rules in Russian and German Tax Law: The Comparison of Collision Resolution Practices. Journal of Tax Reform, 2016, vol. 2, no. 1, pp. 59-84. DOI 10.15826/itr.2016.2.1.017.

40. PwC. 10 Minutes on the OECD's BEPS project. PricewaterhouseCoopers LLP, 2015, 8 p.

41. OECD. Addressing the Tax Challenges of the Digital Economy, Action 1 - 2015 Final Report. OECD/G20 Base Erosion and Profit Shifting Project. OECD Publishing, Paris, 2015. 285 p. DOI: 10.1787/9789264241046-en.

42. Juranek S., Schindler D., Schjelderup G. Transfer pricing regulation and taxation of royalty payments. Journal of Public Economic Theory, 2017, vol. 20, iss. 1, pp. 67-84. DOI: 10.1111/ipet.12260.

43. Yin S., Kaynak O. Big Data for Modern Industry: Challenges and Trends. Proceedings of the IEEE, 2015, vol. 103, no. 2, pp. 143-136. DOI: 10.1109/JPROC.2015.2388958.

44. Hu H., Wen Y., Chua T.-S., Li X. Towards scalable systems for big data analytics: A technology tutorial. IEEE Access, 2014, vol. 2, pp. 652-687. DOI: 10.1109/access.2014.2332453.

45. Gillis T., McStocker A., Percival A. Indirect Tax Compliance in an Era of Big Data. Tax Planning International: Indirect Taxes, 2015, vol. 13, no. 3, pp. 1-6.

46. Vamsi C. How Modern Taxation can benefit from Big Data Analytics. Vamsitalkstech.com, 2017. Available at: http://www.vamsitalkstech.com/?p=2612.

47. Morgan S. Cybersecurity Ventures predicts cybercrime damages will cost the world $\$ 6$ trillion annually by 2021. Cybersecurity Ventures, 2017. Available at: https://cybersecurityventures. com/hackerpocalypse-cybercrime-report-2016/

48. McKinsey Global Institute. The internet of things: mapping the value beyond the hype. McKinsey\&Company, 2015. $131 \mathrm{p}$. 
49. World Economic Forum. Personal Data: The Emergence of a New Asset Class. An Initiative of the World Economic Forum. 2011. 39 p.

50. Koroleva A. The court complicated the life of big data in Russia. Expert.ru, 2018. Available at: http://expert.ru/2018/01/30/sud-oslozhnil-zhizn-big-data-v-rossii/ (In Russ.).

51. Madsbjerg S. It's Time to Tax Companies for Using Our Personal Data. Nytimes.com, 2017. Available at: https://www.nytimes.com/2017/11/14/business/dealbook/taxing-companiesfor-using-our-personal-data.html.

52. Voisin G. A new tax on personal data collection? Bird \& Bird, 2013. Available at: https:// www.twobirds.com/en/news/articles/2013/a-new-tax-personal-data-collection0113.

53. McKinsey Global Institute. Jobs Lost, Jobs Gained: Workforce Transitions in a Time of Automation. Executive Summary. McKinsey \& Company, December 2017. 21 p.

54. Delvaux M. Draft Report with recommendations to the Commission on Civil Law Rules on Robotics (2015/2103(INL)). European Parliament, Committee on Legal Affairs, 31.5.2016. 22 p.

55. Delaney K. The robot that takes your job should pay taxes, says Bill Gates. Quartz, 2017. Available at: https:// qz.com/911968/bill-gates-the-robot-that-takes-your-job-should-pay-taxes/.

56. Sung-Won Y. Korea takes first step to introduce 'robot tax'. Korea Times, 2017. Available at: http://www.koreatimes.co.kr/www/news/tech/2017/08/133 234312.html.

57. Simon M. Tax the Rich and the Robots? California's Thinking About It. WIRED, 2017. Available at: https://www.wired.com/story/tax-the-rich-and-the-robots-californias-thinking-about-it/.

58. Walker J. Robot Tax - A Summary of Arguments "For" and "Against". TechEmergence. 2017. Available at: https://www.techemergence.com/robot-tax-summary-arguments/.

59. Varoufakis Y. A Tax on Robots? Project Syndicate, 2017. Available at: https:// www.project-syndicate.org/commentary/bill-gates-tax-on-robots-by-yanis-varoufakis2017-02? barrier=accessreg.

60. Varoufakis Y. The Universal Right to Capital Income. Project Syndicate, 2016. Available at: https:// www.project-syndicate.org/commentary/basic-income-funded-by-capital-incomeby-yanis-varoufakis-2016-10.

61. Kimball M. Why the US needs its own sovereign wealth fund. Quartz, 2013. Available at: https://qz.com/40235/why-the-us-needs-its-own-sovereign-wealth-fund/.

62. Smith N. What's Wrong with Bill Gates' Robot Tax. Bloomberg.com, 2017. Available at: https:// www.bloomberg.com/view/articles/2017-02-28/what-s-wrong-with-bill-gates-robot-tax.

63. Pinson J., Frost T., Cooper Gr. Tax in the Age of Blockchain. Tax Brief. Greenwoods \& Herbert Smith Freehills Pty Ltd, 2016. 4 p.

64. Lihuta V., Kaplan A. Gadomskiy D., Korol K., Geletkanich O., Gavryilyak O., Otter T. Legal regulation of the cryptocurrency business. Axon Partners and ForkLog Research, 2017. 101 p. (In Russ.).

65. Tjing L. Regulating Cryptocurrencies. BBH Foreign Exchange. 2018 First Quarter Outlook. Brown Brothers Harriman \& Co., 2018. 4 p.

66. Peaster W. Bitcoin, Cryptocurrency and Taxes: What You Need to Know. Blockonomi, 2018. Available at: https://blockonomi.com/cryptocurrency-taxes/.

67. Jia C., Xiaojin R. PBOC gets tougher on bitcoin. Chinadaily.com.cn, 2018. Available at: http://www.chinadaily.com.cn/a/201801/05/WS5a4eb4cba31008cf16da527c.html.

68. Reuters Staff. PBOC governor says Bitcoin not a legitimate method of payment. www.reuters. com, 2018. Available at: https://www.reuters.com/article/us-china-parliament-pboc-risks/ pboc-governor-says-bitcoin-not-a-legitimate-method-of-payment-idUSKCN1GL0FR.

69. Kantyishev P. Putin instructed to come up with a tax on "mining". Vedomosti.ru, 2017. Available at: https://www.vedomosti.ru/technology/articles/2017/10/24/739182-nalog-namaining (in Russ.).

70. Hlushchenko N. Ukraine plans to implement bitcoin use under the oversight of National Bank. 112.ua, 2018. Available at: https://112.international/article/ukraine-plans-to-implement-bitcoin-use-under-the-oversight-of-national-bank-21702.html.

71. Mougayar W. Tokenomics - A Business Guide to Token Usage, Utility and Value. Medium, 2017. Available at: https://medium.com/@wmougayar/tokenomics-a-business-guide-to-token-usage-utility-and-value-b19242053416.

72. Rapoza K. As Bitcoin Struggles, Will Investor Interest in ICOs Weaken? Forbes.com, 2018. Available at: https://www.forbes.com/sites/kenrapoza/2018/02/07/as-bitcoin-struggleswill-investor-interest-in-icos-weaken/\#3d107317433a.

73. Cross T. Planning to Do an ICO? Don't Forget About Taxes. Forbes, 2018. Available at: https:// www.forbes.com/sites/tysoncross/2017/11/21/planning-to-do-an-ico-dont-forgetabout-taxes/\#69c695ad2a91. 
74. Grlica I. Is an ICO a taxable event for the EU VAT purposes? Medium, 2017. Available at: https://medium.com/@IvoGrlica/is-an-ico-a-taxable-event-for-the-eu-vat-purposes-9ed$3 \mathrm{cb} 31417 \mathrm{~b}$.

75. Steveni J., Smith P. Blockchain - will it revolutionize tax? PWC Tax Blog, 2016. Available at: http:// pwc.blogs.com/tax/2016/07/blockchain-will-it-revolutionise-tax.html.

76. PwC. How blockchain technology could improve the tax system. PricewaterhouseCoopers LLP, 2016. 5 p.

77. Flynn C. Preparing for Digital Taxation in a Blockchain World. Tax Planning International Review. October 2016. 4 p.

78. Vigna P., Casey M. The Age of Cryptocurrency: How Bitcoin and the Blockchain Are Challenging the Global Economic. Picador, Reprint edition, 2016. 384 p.

79. Mankiw G, Weinzierl M., Yagan D. Optimal Taxation in Theory and Practice. The Journal of Economic Perspectives, 2009, vol. 23, no. 4, pp. 147-174. DOI: 10.1257/jep.23.4.147.

80. Genkin A. Cryptocurrencies attract people with a strike gold syndrome. Invest Foresight, 2017. Available at: https://investforesight.com/artem-genkin-cryptocurrencies/.

81. Demidov O. Connected by one blockchain: review of international experience in cryptocurrency regulation. Security index, 2015, vol. 21, no. 2 (113), pp. 41-60. (In Russ.).

\section{Authors}

Valentine P. Vishnevsky - Academician of NAS of Ukraine, Doctor of Economics, Professor, Head of the Department of Financial and Economic Problems of the Production Potential Use, Institute of Industrial Economics of the National Academy of Science of Ukraine (2 Zhelyabova St., 03057, Kyiv, Ukraine); ORCID: 0000-00028539-0444; e-mail: vvishn@gmail.com

Viktoriia D. Chekina - Candidate of Economic Sciences, Senior Researcher, Leading Researcher of the Department of Financial and Economic Problems of the Production Potential Use, Institute of Industrial Economics of the National Academy of Science of Ukraine (2 Zhelyabova St., 03057, Kyiv, Ukraine); ORCID: 0000-0003-2118-901X; e-mail: vdchekina@gmail.com

\section{Информация об авторах}

Вишневский Валентин Павлович - академик НАН Украины, доктор экономических наук, профессор, заведующий отделом финансово-экономических проблем использования производственного потенциала, Институт экономики промышленности НАН Украины (03057, Украина, г. Киев, ул. Желябова, 2); ORCID: 0000-0002-8539-0444; e-mail: vvishn@gmail.com

Чекина Виктория Денисовна - кандидат экономических наук, старший научный сотрудник, ведущий научный сотрудник отдела финансово-экономических проблем использования производственного потенциала, Институт экономики промышленности НАН Украины (03057, Украина, г. Киев, ул. Желябова, 2); ORCID: 0000-0003-2118-901X; e-mail: vdchekina@gmail.com

\section{For citation}

Vishnevsky V. P., Chekina V. D. Robot vs. tax inspector or how the fourth industrial revolution will change the tax system: a review of problems and solutions. Journal of Tax Reform, 2018, vol. 4, no. 1, pp. 6-26. DOI: 10.15826/jtr.2018.4.1.042

\section{Аия цитирования}

Вишневский В. П. Робот против налогового инспектора, или как изменит налоговую систему четвертая промышленная революция: обзор проблем и решений / В. П. Вишневский, В. Д. Чекина // Journal of Tax Reform. - 2018. - Т. 4, № 1. - C. 6-26. - DOI: 10.15826/jtr.2018.4.1.042

\section{Article info}

Received March 14, 2018; accepted April 10, 2018

\section{Информация о статье}

Дата поступления 14 марта 2018 г.; дата принятия к печати 10 апреля 2018 г. 